\title{
Monitoring of Forest Resource Health in Akure Reserve, Ondo State Nigeria
}

\author{
V. Ayodele Ijaware
}

\section{ABSTRACT}

\begin{abstract}
Remote sensing and Geographic Information System (GIS) over the years play great role when integrated in the right way to study changes taken place on the planet. Most times, these changes are natural and beyond human interaction but often times too, the changes are occasioned by human factor in the search for development and daily survival. In achieving this, the forest is made to suffer unnecessarily thereby reducing its health status through excessive forest resources depletion. This study focusses on the monitoring of forest resource health in Akure forest reserve between 1972 and 2013 using Landsat MSS of 11/11/1972, Landsat TM of 17/12/1986, Landsat ETM+ of 03/01/2002, and Landsat ETM+ of 02/02/2013 downloaded from USGS website. Minimum Mahalanobis distance supervised classification was used to categorize land use pattern in the study area while ILWIS 3.2 Academic GIS was deployed to perform NDVI image classification analysis with a precision of $0.01 \mathrm{~m}$ to determine the health status of the forest reserve. The analysis revealed that the total annual rate of depletion for 41 years stood at $2.46 \%$ while forest health status diminished during the study period as NDVI value ranged between 0.04 to $+0.44(1972)$ to -1.0 to +1.0 in 2013 . The study recommends that open areas which are not homogeneous forest (shrub/grass land) detected in this study should be re-planted with varieties of tree species without delay to allow carbon sequestration for overall human benefits.
\end{abstract}

Keywords: Mahalanobis, Nearest neighbor algorithm, Nigerian Forestry Information System (NFIS), Normalized Difference Vegetation.

\section{INTRODUCTION}

Akure forest reserve has undergone very profound and important paradigmatic and methodological changes occasioned by human activities. Forest products had in the past contributed its quota to the Nigerian GDP in terms of foreign exchange earnings from timber exports as well as money earned from using forest products as structural material in the construction industries. The demand for forest product is high since almost everybody depends on the forest for food, charcoal, furniture, herbs, and also as major raw material for construction industries. Apart from this, the forest land has been used as a platform by government in carrying out projects such as: electricity transmission lines, water and oil pipelines, road alignment/construction, and innovative agricultural schemes across the country, and establishment of industries, government urban expansion programs and the moribund annual tree planting exercise among others. The major content of the Nigerian vegetation includes high forests, plantations, and trees in free zones. However, in 1950's before Nigerian population reach the present estimated value of about 193 million [11] forest trees were virtually found everywhere and the demand for tree were not as high as it is now. As the population increases and Governments of Nigeria at different times failed to provide basic household infrastructure for cooking, electricity poles and alternative for various timber products use in the country, made the biodiversity loss.
Submitted : April 08, 2021

Published : May 06, 2021

ISSN: $2684-1827$

DOI: $10.24018 /$ ejfood.2021.3.3.282

\section{A. Ijaware*}

Department of Surveying and Geoinformatics, Federal University of Technology Akure, Ondo State, Nigeria. (e-mail: vaijaware@futa.edu.ng)

*Corresponding Author

Nigerian forest reserve at various location across the nation the last resort for livelihood.

In Ondo state for an example, the state government's youth in agricultural program contributed immensely to the forest depletion in the state and the conversion of forest land into farmland [2]. Other contributory factors in the past included the intentional access to the forest reserve for cultivation in the 1990s that attracted farmers from multi communities within and outside the South western part of Nigeria and the various onslaughts against forest ecosystem that did not allow for self-regenerating resulting into

This study aimed to monitor forest resources in Akure reserve with the intention of solving some of the identified inherent problems which will provide suitable avenue for determining forest health status for four decades starting from 1972. In other to achieve the main purpose of the study, the following questions become imperative: (i) what are the various land use and land cover categories in the study area? (ii) What are the extents of identified land use and land cover categories, and (iii) what is the health status of the forest reserve for four decades? To provide logical solutions, time series satellite imageries and Geographic Information System was deployed to determine the land use and land cover categories in the study area, and it was also used to generate forest health status from Normalized Difference Vegetation Index (NDVI) for each of the years under considerations. 
The amount of forest lost to deforestation were not based on actual values but on estimated values [5], [19], and [16] because forest administration and management in Nigeria is decentralized with each State managing forest resources within her geographical boundary independently [6]. The Nigerian Forestry Information System (NFIS) developed by the Forestry Association of Nigeria for the Federal Department of Forestry with the financial support provided by the Food and Agriculture Organization of the United Nations (FAO), which was supposed to contain relevant spatial information from the forestry sub-sector was completely devoid of data from the 36 States of the Country. However, previous notable researches like [15], [9], [13], [14], [12], [4], [3], and [7] among others based their studies on deforestation, land use and land cover changes, and forest management in Nigerian forest reserves. None of these studies contributed their research outcome to the Nigerian Forestry Information System (NFIS). The present study therefore assessed the health of vegetation cover in Akure reserves using NDVI with the intention of providing relevant spatial data from one of the prominent forest reserves in Ondo state with the sole aim of contributing it to NFIS been the gap this study which to fill to do the final formatting of your paper.

\section{MATERIALS AND METHODS}

\section{A. Material Collection and Preparation of Samples}

The type of data sources used for this research work was classified as primary and secondary data. The primary data were obtained using Global Positioning System (GPS) to record coordinates of points used for map georeferencing while the secondary data were extracted from the topographical map of Ondo state produced in 1966 by Federal Surveys, Lagos described as Ondo sheet 263 (NE and SE) and Ondo sheet 264 (NE, NW, SE, and SW). Each sheet was geo-referenced, geo-coded and glued together (edge matching) to form a composite digital topographic map covering the study area. The geo-reference activities were based on UTM Zone 31 and WGS 84 ellipsoid. Also, Landsat MSS of 11/07/1972, Landsat TM of 17/12/1986, Landsat ETM+ of 03/01/2002, and Landsat ETM+ of 2013 were downloaded from USGS website with resolutions ranging between $15-40 \mathrm{~m}$. In addition, extensive selective ground truth survey was carried out to confirm the various land use and land cover classes in the study area.

Each raw data for the different epoch were uploaded into ILWIS 3.2 Academic GIS software for processing. The false color composite image was georeferenced by adding tiepoints. The software was used to sub-map the 1972, 1986, 2002 and 2013 color composite image using the geographical coordinates $(\phi, \lambda)$ of the frame edge. The four sub-maps were geo-referenced using the same geographic coordinates of the frame edges defining its perimeter. Linear rectification was carried out on all four images and the Root Mean Square (RMS) error was checked and found to be below the stipulated $0.5 \mathrm{~m}$ displacement error. The images were later re-sampled using Nearest neighbor algorithm.

Prior to the image classification, map list and a domain were specified in other to create sample set. Also, a sample pixel (training pixel) was equally created, and class names were assigned to groups of pixels that represent a known feature on the ground which also have similar spectral values on the maps in the map list based on past experience and familiarity with the study area. A total of seven (7) training sets were identified as built-up areas, cultivation, dense forest, light forest, rock outcrop, secondary re-growth and water bodies corresponding with the types of land use land cover predominant in the study area in line with [2] classification scheme.

Sizeable numbers of the classes of the training sets above were identified and interactively digitized on screen. The ILWIS 3.2 Academic software was trained to recognize spectral values or signature associated with the training sets to classify the remaining pixels (supervised classification) using Minimum Distance (MD) algorithm on bands 432 into the various land use patterns prominent in the study area Post classification was carried out to eliminate shadow casted by the sun on the rock which showed equal spectral reflectance possessed by water body with Minimum Mahalanobis Distance (MMD) algorithm [10] and inherent classification problems minimized [8].

The result of the MMD land use and land cover pattern classes was polygonized (vectorized) and stored in attribute tables. However, for the purpose of analysis, the polygonized map was re-converted back into raster image using $10 \mathrm{~m}$ resolution to enable further processing in Arc Map GIS environment. The composite digital topographic map was later updated, sub-mapped and re-sampled using nearest neighbor algorithm. The rasterized polygon land use and land cover image was later super imposed on the submapped updated digital topographical map in other to know at a glance the settlement that surrounded the forest as well as access roads to the forest reserve. Thereafter, the NDVI values which indicates the presence, land cover change and health condition of green vegetation was calculated from two satellite bands: visible or red reflectance and nearinfrared reflectance values. Specifically, NDVI classification of $0.01 \mathrm{~m}$ precision was carried out on the filtered sub-map Landsat images of 1972, 1986, 2002, and 2013, sequentially.

\section{RESULTS AND DISCUSSION}

Different land use and land cover supervised classification maps for the study area was produced for the various years under investigation (Fig. 1). Seven land use was discovered in the classification of Akure forest reserve namely: built-up areas, cultivation, dense forest, light forest, rock outcrop, secondary re-growth, and water bodies. The results of the area(ha)occupied by the various classes on the maps was generated by the software which were extracted and presented in Table $\mathrm{I}$ and the corresponding chats displayed as Fig. 2 a-d.

It is obvious from Table I that built-up area increases from $2.01 \%$ in 1972 to $6.64 \%$ in 2013 due to influx of people to Akure been the state capital. In the contrary, dense forest decreased from $10.74 \%$ in 1972 to $0.39 \%$ in 2002 and it further deceased to $4.75 \%$ in 2013 while the total annual rate of depletion for 41 years stood at $2.46 \%$. Hence it can be remarked that when dense forest is on the decline and 
cultivation increases from $18.98 \%$ in 1972 to $38.29 \%$ in 2013 (Fig. 2 a-d).

TABLE I:LU/LC CROSS TABLES FOR 1972 AND 1986

\begin{tabular}{|c|c|c|c|c|c|c|c|c|}
\hline ID & $\begin{array}{c}\text { Area (ha) } \\
1972\end{array}$ & $\begin{array}{c}\text { Area }(\%) \\
1972\end{array}$ & $\begin{array}{c}\text { Area (ha) } \\
1986\end{array}$ & $\begin{array}{c}\text { Area }(\%) \\
1986\end{array}$ & $\begin{array}{c}\text { Area (ha) } \\
2002\end{array}$ & $\begin{array}{c}\text { Area }(\%) \\
2002\end{array}$ & $\begin{array}{c}\text { Area (ha) } \\
2013\end{array}$ & $\begin{array}{c}\text { Area }(\%) \\
2013\end{array}$ \\
\hline Built up & 2176.189 & 2.01252 & 2431.928 & 2.249024 & 3856.762 & 3.566697 & 7180.121 & 6.64011 \\
\hline Cultivation channel & 20525.002 & 18.9813 & 37269.9 & 34.46685 & 36534.11 & 33.7864 & 41399.73 & 38.2861 \\
\hline Dense forest & 11615.34 & 10.7418 & 5995.718 & 5.544783 & 422.04 & 0.390299 & 5135.661 & 4.74941 \\
\hline Light forest & 53633.422 & 49.5997 & 54315.69 & 50.23063 & 61242.55 & 56.63653 & 44331.67 & 40.9975 \\
\hline Rock out crop & 2566.941 & 2.37388 & 6163.92 & 5.700335 & 4784.075 & 4.424267 & 5467.286 & 5.05609 \\
\hline Secondary regrowth & 17418.472 & 16.1084 & 1761.618 & 1.629128 & 1216.74 & 1.12523 & 3538.561 & 3.27243 \\
\hline Water body & 197.233 & 0.1824 & 193.829 & 0.179251 & 76.321 & 0.070581 & 1079.57 & 0.99838 \\
\hline Total & 108132.6 & 100 & 108132.6 & 100 & 108132.6 & 100 & 108132.6 & 100 \\
\hline
\end{tabular}
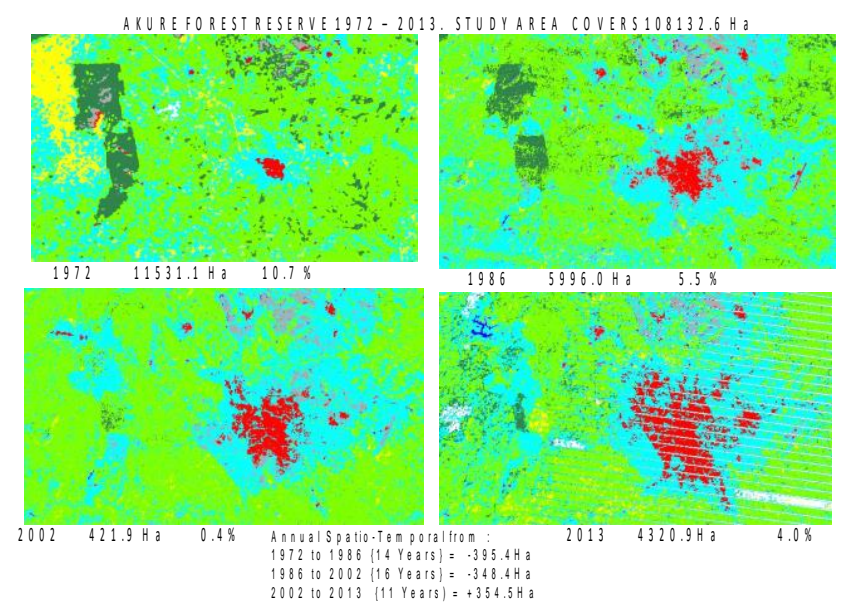

Fig. 1. Annual Spatial Temporal depletion of Akure forest reserve between 1972-2013.

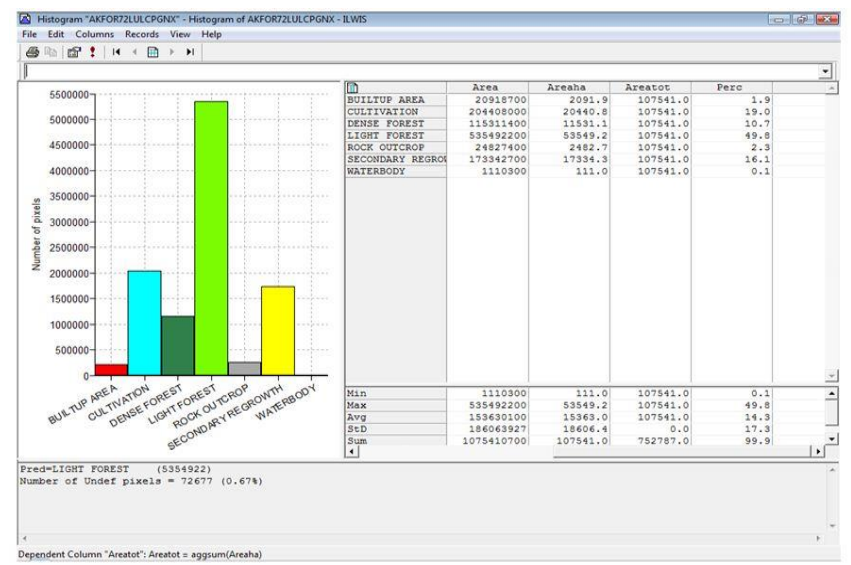

Fig. 2 (a). Histogram showing land use and land cover for 1972.

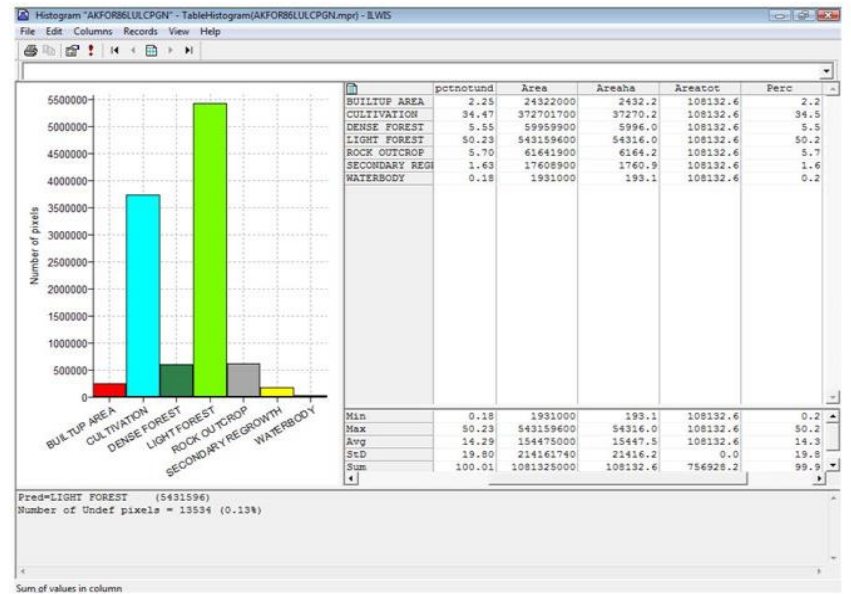

Fig. 2 (b). Histogram showing land use and land cover for 1986.

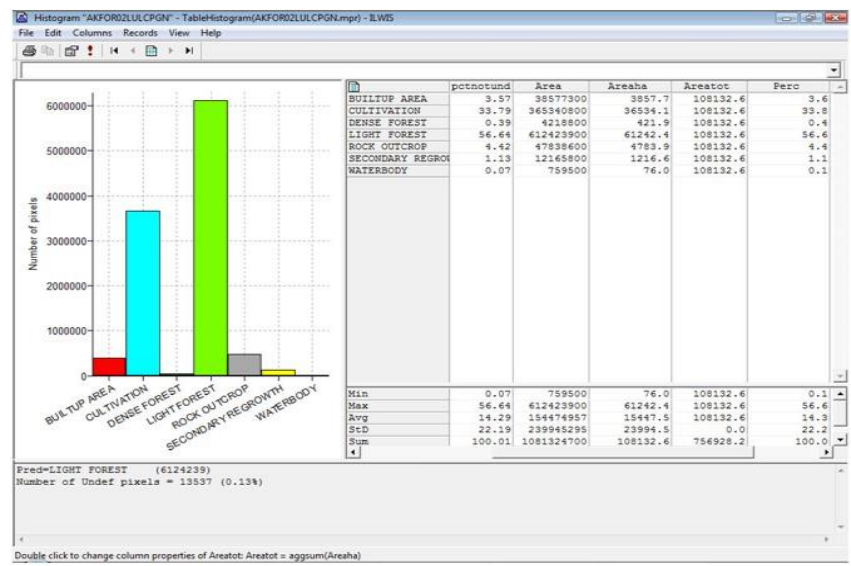

Fig. 2 (c). Histogram showing land use and land cover for 2002.

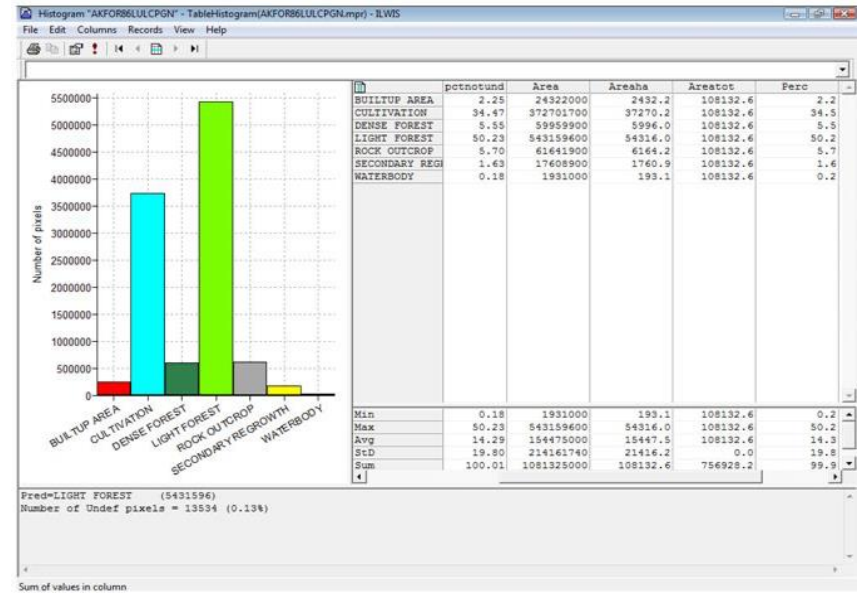

Fig.2 (d). Histogram showing land use and land cover for 2013.

Similarly, during the same epoch under consideration, rock outcrop which were covered up with forest in 1972 increases from $2.37 \%$ to $5.06 \%$ in 2013 . This was because of the springing up of various quarry companies, construction of roads and dams and the demand for high quality construction materials by the people which led to hewing of forest trees. Light forest on the other hand, occupies the highest area in the study area. It increases from $49.60 \%$ in 1972 to $56.64 \%$ in 2002 but declined below average (41\%) in 2013 owing to the presence of secondary re-growth that witness's rejuvenation of hewed forest trees between 2002 and 2013 which serves as gain to dense forest during the same year. However, various combinations of overlay operations performed on the maps for 1972 and 1986; 1986 and 2002; and 2002 and 2013 gave an output cross map shown as Fig. 3 (a), (b), and (c) as well as cross Tables II-IV. Investigation and analysis of the cross tables 
revealed that between 1972-1986; 1986-2002; 2002-2013 and 1972-2013, dense forest area that turned into cultivation was 2639.6 ha, 1952.9 ha, 89.2 ha, and 4681.7 ha, respectively. Similarly, dense forest area that became rock outcrop, water bodies, built-up area, and light forest -i.e., shrub/grass was 860.2 ha, 98.0 ha., 28.5 ha., and 8173.3 ha for 1972-1986; 1986-2002; 2002-2013, and 1972-2013 epochs under consideration.

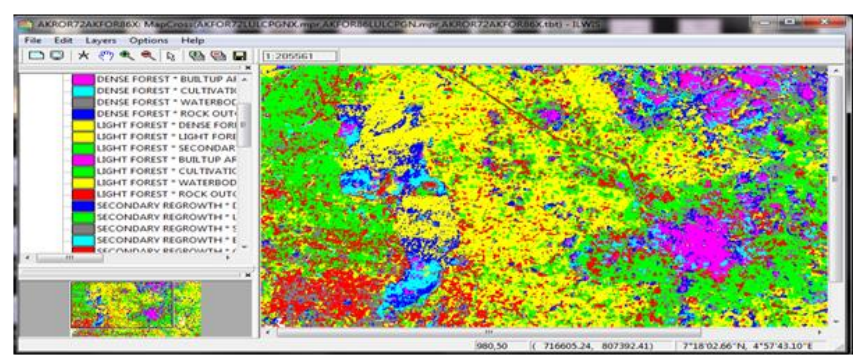

Fig. 3 (a). LU/LC Cross map for 1972 and 1986.

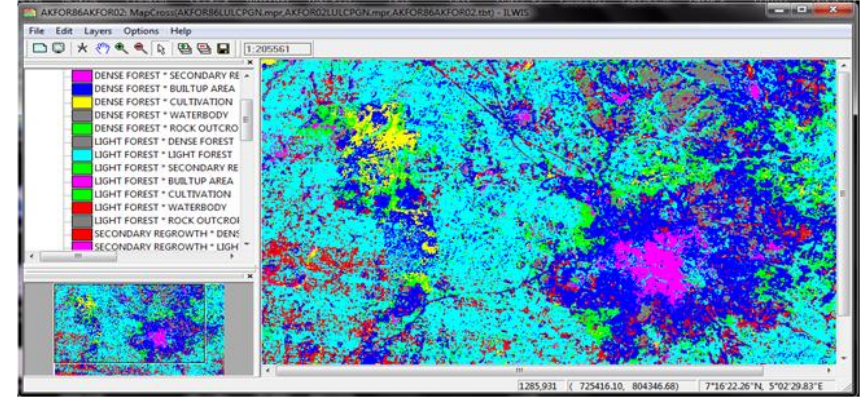

Fig. 3 (b). LULC cross map for 1986 and 2002.

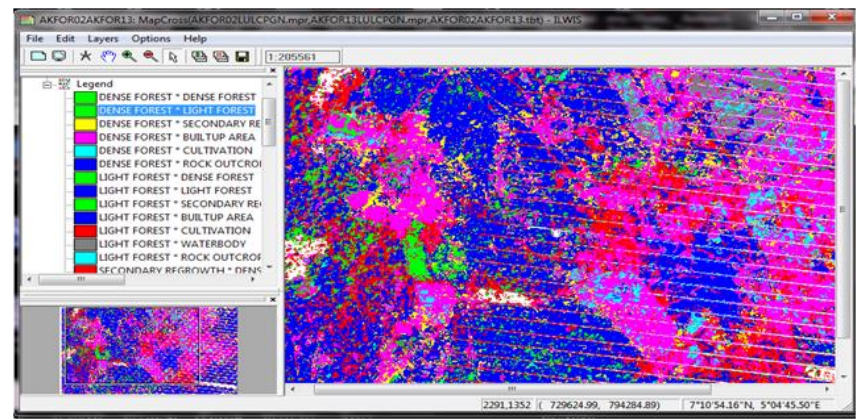

Fig. 3 (c). LU/LC Cross map for 1972 and 1986.

TABLE II:LU/LC CROSS TABLES FOR 1972 AND 1986

\begin{tabular}{ccccccc}
\hline \hline ID & & NPix & Area & Area (ha) & Area (Total) & Percentage (\%) \\
\hline Dense forest & Built up area & 1727 & 172700 & 17.3 & 107474.3 & 0.0 \\
& Cultivation & 263963 & 26396300 & 2639.6 & 107474.3 & 2.5 \\
& Water body & 9088 & 908800 & 90.9 & 107474.3 & 0.1 \\
& Rock outcrop & 83248 & 8324800 & 832.5 & 107474.3 & 0.8 \\
Minimum & & 1 & 100 & 0.0 & 107474.3 & 0.0 \\
Maximum & & 3148608 & 314860800 & 31486.1 & 107474.3 & 29.3 \\
Average & 219335 & 21933498 & 2193.4 & 107474.3 & 2.0 \\
Std Deviation & 540913 & 54091344 & 5409.1 & 0.0 & 5.0 \\
Sum & & 10747414 & 1074741400 & 107474.3 & 5266240.7 & 100.0 \\
\hline \hline
\end{tabular}

TABLE III:LU/LC CROSS TABLES FOR 1986 AND 2002

\begin{tabular}{|c|c|c|c|c|c|c|}
\hline ID & & NPix & Area & Area (ha) & Area (Total) & Percentage $(\%)$ \\
\hline \multirow[t]{4}{*}{ Dense forest } & Built up area & 1096 & 109600 & 11.0 & 108132.7 & 0.0 \\
\hline & Cultivation & 195292 & 19529200 & 1952.9 & 108132.7 & 1.8 \\
\hline & Water body & 706 & 70600 & 7.1 & 108132.7 & 0.0 \\
\hline & Rock outcrop & 2302 & 230200 & 23.0 & 108132.7 & 0.0 \\
\hline Minimum & & 38 & 3800 & 0.4 & 108132.7 & 0.0 \\
\hline Maximum & & 4430061 & 443006100 & 44300.6 & 108132.7 & 41.0 \\
\hline Average & & 254756 & 25475561 & 2457.6 & 108132.7 & 2.3 \\
\hline Std Deviation & & 757693 & 75769258 & 7576.9 & 0.0 & 7.0 \\
\hline Sum & & 10813247 & 1081324700 & 108132.7 & 4757838.8 & 100.0 \\
\hline
\end{tabular}

TABLE IV:LU/LC CROSS TABLES FOR 2002 AND 2013

\begin{tabular}{ccccccc}
\hline \hline ID & & NPix & Area & Area (ha) & Area (Total) & Percentage $(\%)$ \\
\hline Dense forest & Built up area & 15783 & 1578300 & 157.8 & 102382.6 & 0.2 \\
& Cultivation & 1716 & 171600 & 17.2 & 102382.6 & 0.0 \\
& Water body & 19 & 1900 & 0.2 & 102382.6 & 0.0 \\
& Rock & 8916 & 891600 & 89.0 & 102382.6 & 0.1 \\
Minimum & outcrop & 2 & 200 & 0.0 & 102382.6 & 0.0 \\
Maximum & & 3660621 & 366062100 & 36606.2 & 102382.6 & 35.8 \\
Average & & 227516 & 22751636 & 2275.2 & 102382.6 & 2.2 \\
Std Deviation & & 661670 & 66166995 & 6616.7 & 0.0 & 6.5 \\
Sum & & 10238236 & 1023823600 & 102382.6 & 4607217.0 & 99.8 \\
\hline \hline
\end{tabular}

The Accuracy of the classification process determined by generation of confusion matrix shown as Tables V and VI was found to be $66.64 \%$ and $62.98 \%$ for all classes of overlay for the year 1986/2002 and 2002/2013, respectively. It was discovered that light forest has classification accuracies of $82 \%$ and $63 \%$ for $1986 / 2002$ and $2002 / 2013$ epoch while dense forest has $40 \%$ and $34 \%$ classification accuracies for the same period under review. 
TABLE V:LU/LC CROSS TABLES FOR 2002 AND 2013

\begin{tabular}{ccccccc}
\hline \hline ID & & NPix & Area & Area (ha) & Area (Total) & Percentage (\%) \\
\hline Dense forest & Built up area & 15783 & 1578300 & 157.8 & 102382.6 & 0.2 \\
& Cultivation & 1716 & 171600 & 17.2 & 102382.6 & 0.0 \\
& Water body & 19 & 1900 & 0.2 & 102382.6 & 0.0 \\
& Rock outcrop & 8916 & 891600 & 89.0 & 102382.6 & 0.1 \\
Minimum & & 2 & 200 & 0.0 & 102382.6 & 0.0 \\
Maximum & & 3660621 & 366062100 & 36606.2 & 102382.6 & 35.8 \\
Average & & 227516 & 22751636 & 2275.2 & 102382.6 & 2.2 \\
Std Deviation & & 661670 & 66166995 & 6616.7 & 0.0 & 6.5 \\
Sum & & 10238236 & 1023823600 & 102382.6 & 4607217.0 & 99.8 \\
\hline \hline
\end{tabular}

TABLE VI: CONFUSION MATRIX FOR 1986/2002

\begin{tabular}{|c|c|c|c|c|c|c|c|c|c|}
\hline ID & $\begin{array}{l}\text { Dense } \\
\text { Forest }\end{array}$ & $\begin{array}{l}\text { Light } \\
\text { Forest }\end{array}$ & $\begin{array}{l}\text { Secondary } \\
\text { Regrowth }\end{array}$ & $\begin{array}{c}\text { Built up } \\
\text { Area }\end{array}$ & Cultivation & $\begin{array}{l}\text { Water } \\
\text { Body }\end{array}$ & Rock Outcrop & Unclassified & Accuracy \\
\hline Dense forest & 21067 & 376377 & 2758 & 1096 & 195292 & 706 & 2302 & 0 & 0.04 \\
\hline Light Forest & 19328 & 4430061 & 69803 & 6983 & 897320 & 483 & 7618 & 0 & 0.82 \\
\hline $\begin{array}{l}\text { Secondary } \\
\text { Regrowth }\end{array}$ & 39 & 114617 & 27886 & 1453 & 31597 & 0 & 497 & 0 & 0.16 \\
\hline Built up Area & 0 & 173 & 54 & 196607 & 30905 & 0 & 15481 & 0 & 0.81 \\
\hline Cultivation & 1595 & 1194683 & 21057 & 93919 & 2250828 & 779 & 164154 & 0 & 0.60 \\
\hline Water Body & 0 & 180 & 38 & 0 & 5687 & 2352 & 11053 & 0 & 0.12 \\
\hline Rock Outcrop & 159 & 8148 & 62 & 85715 & 241779 & 3275 & 277281 & 0 & 0.45 \\
\hline Reliability & 0.50 & 0.72 & 0.23 & 0.51 & 0.62 & 0.31 & 0.58 & 0 & \\
\hline
\end{tabular}

Average Accuracy $=42.76 \%$ Average Reliability $=49.53 \%$.

Overall Accuracy $=66.64 \%$.

TABLE VII: CONFUSION MATRIX FOR 2002/2013

\begin{tabular}{|c|c|c|c|c|c|c|c|c|c|}
\hline ID & $\begin{array}{l}\text { Dense } \\
\text { Forest }\end{array}$ & $\begin{array}{l}\text { Light } \\
\text { Forest } \\
\end{array}$ & $\begin{array}{l}\text { Secondary } \\
\text { Regrowth }\end{array}$ & $\begin{array}{c}\text { Built up } \\
\text { Area }\end{array}$ & Cultivation & Water Body & $\begin{array}{c}\text { Rock } \\
\text { Outcrop }\end{array}$ & Unclassified & Accuracy \\
\hline Dense forest & 14162 & 15783 & 1716 & 19 & 8916 & 0 & 471 & 0 & 0.04 \\
\hline Light Forest & 315838 & 3660621 & 214468 & 33984 & 1453061 & 4525 & 91562 & 0 & 0.82 \\
\hline $\begin{array}{l}\text { Secondary } \\
\text { Regrowth }\end{array}$ & 933 & 55022 & 28257 & 1268 & 25047 & 1801 & 2483 & 0 & 0.16 \\
\hline Built up Area & 0 & 51 & 0 & 288292 & 38046 & 1697 & 38755 & 0 & 0.81 \\
\hline Cultivation & 99131 & 616072 & 27876 & 260427 & 2294689 & 12271 & 167247 & 0 & 0.60 \\
\hline Water Body & 15 & 28 & 0 & 2 & 4860 & 191 & 2347 & 0 & 0.12 \\
\hline Rock Outcrop & 1623 & 1118 & 16 & 52634 & 232578 & 5996 & 162337 & 0 & 0.45 \\
\hline Reliability & 0.03 & 0.84 & 0.10 & 0.45 & 0.57 & 0.01 & 0.35 & 0 & \\
\hline
\end{tabular}

Average Accuracy $=43.60 \%$ Average Reliability $=33.61 \%$ Overall Accuracy $=62.98 \%$.

There were tremendous developmental programs leading to the construction of sports stadium, dual carriage way, Owena dam Argumentation water supply scheme right inside the forest reserve. Also, the construction of the Nigeria Airport Authority's runways and the ubiquitous quarry activities in the study area was responsible for an increased in the low visible value reflectance of NDVI values from -0.04 in 1972 to -1.0 in 1986 , while the nearinfrared reflectance also increased from 0.44 to 0.98 over the same period (Fig. 4 b). Currently, the non-vegetation and vegetation area were at equilibrium and the health status was moderate.

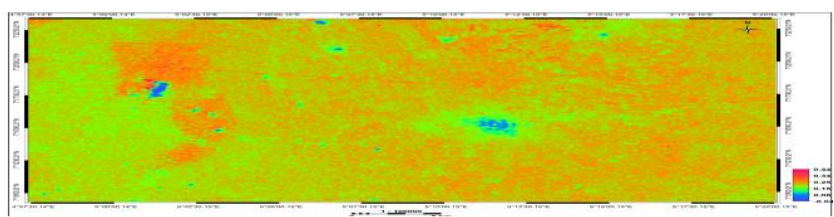

Fig. 4 (a). NDVI 1972 map.

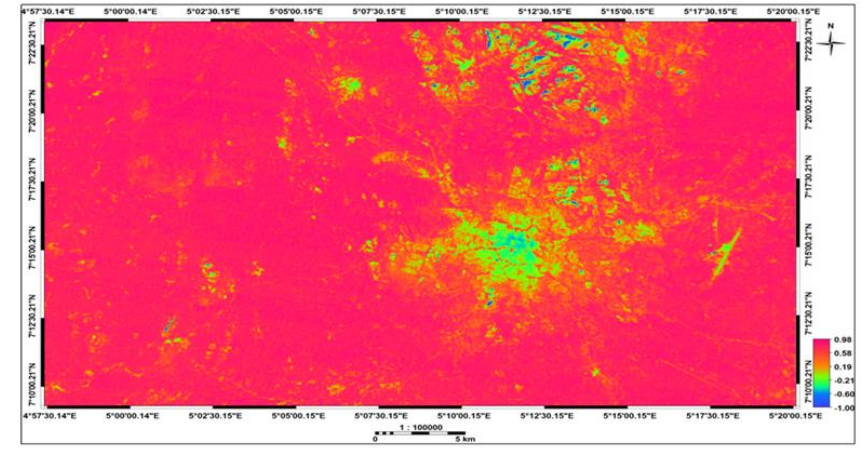

Fig. 4 (b). NDVI 1986 map.

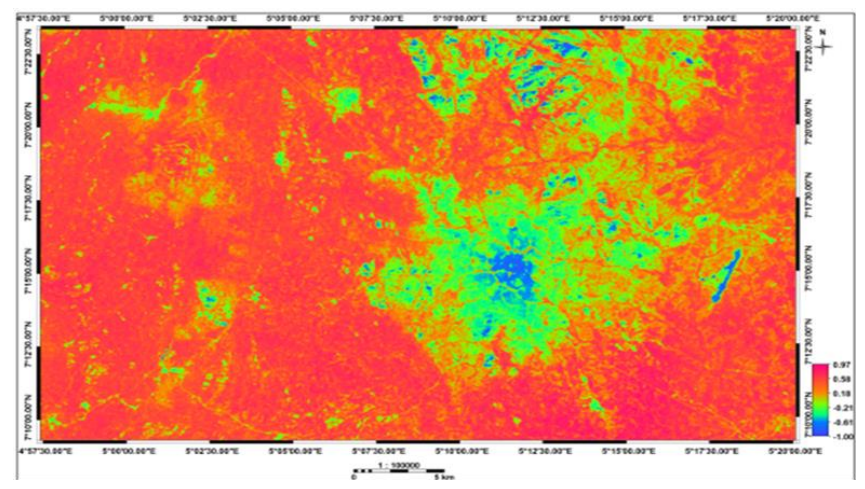

Fig. 4 (c). NDVI 2002 map. 


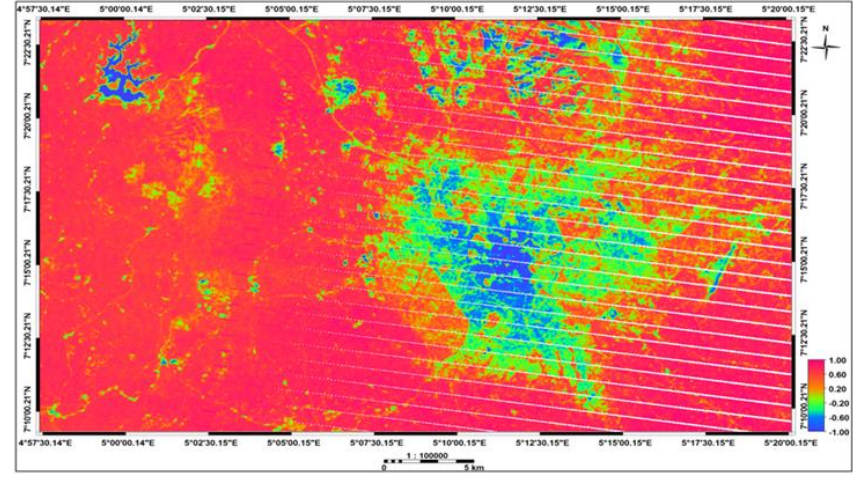

Fig. 4 (d). NDVI2013 map.

Heavy construction activities were the hallmark of 2002. It was during this time that the gigantic Owena multipurpose dam with a capacity of $60,000 \mathrm{~m}^{3}$ per day was constructed inside Akure forest and virtually every trees and other vegetation on site including all vegetation along the river bank was either hewed and made use of or competently destroyed to give way for heavy duty construction equipment. These activities and the continuous growing of Akure township in all direction contributed positively to the NDVI values of -1.0 and +0.97 (Fig. 4 c) obtained at this time indicating a deteriorated forest health in the study area.

The NDVI values of -1.0 and +1.0was obtained for 2013 indicating unhealthy forest reserve (Fig. 4 d). The factors responsible for the NDVI values were seriously connected with the massive urban expansion, more exposure of rocky surfaces due to quarry activities and unabated conversion of forest land into cultivation. However, the formation of composites images for this study helps greatly in minimizing errors associated with perturbing factors of atmospheric effects, clouds, soil effects anisotropic effects, and spectral effects in the accuracy of the various NDVI values obtained in line with Weier and Herring [18].

\section{CONCLUSION}

The changes that occurred over four decades were extracted and carefully analyzed from the Landsat imageries of 1972, 1986, 2002 and 2013. The result of the analysis showed that dense forest was on the decline while cultivation was on the increases and light forest were seen to occupies the highest area in the study area. It was discovered that more than half of the area occupied by dense forest had been cultivated such that the area loss to cultivation serves as gain to light forest because clearing carried out during the construction of Owena multipurpose dam witnessed the sprouting up of grasses. The result obtained in this study was in tandem with the results obtained on forest conversion by [5], [19], and [16]. The result of the NDVI values obtained also confirmed the initial analysis carried out in this study as forest health was on deteriorating trends.

\section{ACKNOWLEDGMENT}

V. A. Ijaware thanks Mr Nnamani O. John for his efforts in proof reading and editing the manuscript.

\section{REFERENCES}

[1] V.A.J. Adekunle, J.O. Okunola, and D.O. Oke, "Management of forest ecosystem for food security and rural livelihood in South West Nigeria", Final project Report for 2011 START Grants for Global Change Research in Africa. 2011, pp 143.

[2] J. R. Anderson, A land use and land cover classification system for use with remote sensor data Washington: US Government Printing Office, 1984, Vol. 964

[3] O. Eludoyin, and O. O. Iyanda, (2018). Land cover change and forest management strategies in Ife nature reserve, Nigeria. GeoJournal [Online]Available:https://www.researchgate.net/publication/3279439 44.

[4] G. O. Enaruvbe, and O. P. Atafo, "Analysis of deforestation pattern in the Niger Delta region of Nigeria" Journal of Land Use Science, vol 11(1), pp 113-130, 2016.

[5] Food and Agriculture Organization (FAO) (1990). Forest resources assessment, 1990: Tropical Countries. FAO Forestry paper 112, Rome, Italy.

[6] Forestry Association of Nigeria (FAN) (2014). Nigerian Forestry Information System. Available: at http://www.nfis.gov.ng/index.php/state-information/ondo-state290.

[7] I.A. Gbiri, and N.O. Adsoye, "Analysis of pattern of deforestation in Akure forest reserve, Ondo State", Nigeria. Journal of Environmental Geography, vol 12(1-2), pp 1-11, 2019.

[8] B. Gorte, "Spatial Statistics for Remote Sensing: Description of data used in this book" In Stein, A.; Van der Meer, F.; and Gorte, B. (eds.). London: Kluwer Academic Publishers, 1999, pp. 3-8.

[9] I. A, Ikhuoria, I.I. Ero, and E. A. Ikhuoria, "Imperatives of space for sustainable forest management "Satellite detection and GIS analysis of lowland rainforest reserve reduction in Edo State, Nigeria", In Salami, A.T (ed.). Abuja: Space Application and Environmental Science Laboratory, OAU, Ile- Ife, 2006, Pp. 72-93.

[10] T.M. Lillesand and R.W. Kiefer, "Remote Sensing and Image Interpretation" 3rd Edition. John Wiley \& Sons, Inc., New York. 1994, pp. 750.

[11] National bureau of statistics (2017). Demographic Statistics Bulletin, 3rdediton [Online] Available: http://nigerianstat.gov.ng.

[12] O. O. I. Orimoogunje, "The impact of land use dynamics on Oluwa Forest Reserve in Southwestern, Nigeria", Journal of Landscape Ecology, vol. 7(2), pp. 25-44, 2014.

[13] O. O. I. Orimoogunje, O. Ekanade, and F.A Adesina, "Land use changes and forest reserve management in a changing environment: South-western Nigeria Experience", Journal of Geography and Regional Planning, vol. vol. 2(11), pp. 283-290, 2009.

[14] O.J. Pelemo, C. Adeosun, C.S, Osudiala, and A.C. Adetogun, (2011) "Assessment of growth Dynamics of tree species in SRN2, Akure forest reserves", Nigeria Journal of research in forestry, wildlife, and environment vol. 3(2), pp. 6.

[15] A. T. Salami, "Vegetation dynamics on the fringes of lowland tropical rainforest of Southwestern Nigeria-An assessment of environmental change with Air Photos and Landsat TM", International Journal of Remote Sensing, vol. 20(6), pp. 1169-1182, 1999.

[16] A. T. Salami, Monitoring Nigerian forest with Nigeriasat-1 and other satellite. In Ayobami T. Salami (eds)Imperatives of space technology for sustainable forest management in Nigeria. Ile-Ife: Space Applications \& Environmental Science Laboratory, Obafemi Awolowo University, 2006.

[17] A. T. Salami, O. Ekaanade, and R. O. Oyinloye, (1999), "Detection of forest reserve incursion in south-western Nigeria from a combination of multi-date aerial photographs and high-resolution satellite", imagery. International Journal of Remote Sensing, vol. 20(8), pp. 1487-1497, 1999.

[18] J. Weier and D. Herring, (2000). Measuring Vegetation (NDVI AND EVI): Feature Article, NASA Goddard Space Flight Center [Online] Available:

http://m.earthobservatory.nasa.gov/Features/MeasuringVegetation/.

[19] World Bank (1991). Forest Sector Policy Paper. The World Bank. Washington. DC.

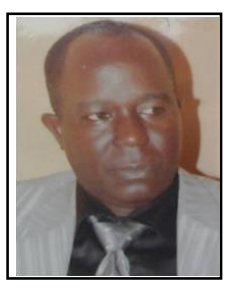

V. A. Ijaware obtained BSc and Msc in Surveying and Geoinformatics Engineering from the University of Lagos in 1997 and 2002 and $\mathrm{PhD}$ degree in Geoinformatics from the University of Benin, Edo state Nigeria in 2019.

He has been an external examiner to Rufus Giwa Polytechnic Owo, Ondo State and Surveyor Council of Nigeria (SURCON) and have supervised Undergraduates, Post Graduate Diploma and Masters 
European Journal of Agriculture and Food Sciences www.ejfood.org

students in Federal University of Technology, Akure Ondo State.

His research interest majors on Remote Sensing and Geographic Information System. He is the current ag Head of Department and also Post Graduate Coordinator of Surveying and Geoinformatics department, Federal University of Technology, Akure, Nigeria.

$\mathrm{He}$ is a registered surveyor and a Member of Nigeria Institution of Surveyors (MNIS) professional body. He won the Craig Endoment Award Maiden Edition and Nigeria Institution of Surveyors Award. 